\title{
Minimál invazív bemeneti kavitás premoláris és moláris fogaknál - irodalmi összefoglalás
}

\author{
DR. BALÁZS MÓNIKA, DR. KOMORA PÉTER, DR. TÓTH ZSUZSANNA
}

\begin{abstract}
A közösségi médiában és a tudományos fórumokon is egyre többször jelennek meg esetbemutatások, melyekben miniatűr bemeneti kavitás(ok)on keresztül végeznek gyökérkezelést a vállalkozó szellemű fogorvosok. Az egyértelmű technikai bravúrhoz elengedhetetlen nagyítás (operációs mikroszkóp használata), megfelelő megvilágítás és múszerezettség. Minimál invazív bemeneti kavitás kialakításával a gyökérkezelés kivitelezése nehezebb és időigényesebb lehet, ezért összetettebb anatómiájú fogaknál csak korlátozottan alkalmazható. Egyszerúbb esetekben azonban, ha a szövettörmelék eltávolítása és a pulpaûr fertőtlenítése biztosított, valós alternatívája lehet a hagyományos bemeneti kavitásoknak. Több koronai foganyag megőrzését teszi lehetővé, így a fog restaurálható marad, de a törési ellenállás növekedését in vitro egyelöre nem sikerült igazolni.
\end{abstract}

Kulcsszavak: minimál invazív bemeneti kavitás, pericervikális dentin, törési ellenállás, operációs mikroszkóp

\section{A bemeneti kavitás}

A gyökérkezelés első lépése a bemeneti kavitás kialakítása, amely kulcsfontosságú a kezelés sikeressége szempontjából. Korrekt gyökérkezelés elvégzése a gyökércsatornák kemo-mechanikai preparálásával valósul meg. Műszereinknek és fertőtlenítő oldatainknak közvetlen kapcsolatba kell kerülniük a gyökércsatornák falával, ez azonban nem érhető el teljes mértékben a gyökércsatorna-rendszer komplexitása miatt. A rendelkezésre álló preparáló eszközök és átöblítő szerek tulajdonságait figyelembe véve a bemeneti kavitás preparálásának célja és alapelvei, melyek az egyetemen oktatásra kerülnek [12]:

- a szuvas foganyag és az elégtelen széli zárású koronai restaurátumok teljes eltávolítása [6, 34]

- az ép foganyag megőrzése [1, 32, 34]

- a pulpakamra tetejének teljes eltávolítása [1,34]

- a pulpaszövet teljes eltávolítása [34]

- az orifíciumok lokalizálása [34]

- egyenes vonalú hozzáférhetőség (EVH) biztosítása a foramen apicale-hoz vagy a csatorna első görbületéhez [1, 6, 34].

A fogak gyökércsatornái többnyire nem egyenes lefutásúak, különösen jellemző az apikális harmad görbülete, de egyes fogaknál már a középső harmadban is találkozhatunk különböző fokú görbületekkel. $E V H$ biztosításával csökkenthető a preparációs hibák előfordulása [26]. Ezeket fóként a vastag, merev acélműszerek okozhatják azáltal, hogy próbálják kiegyenesíteni a gör- bült gyökércsatornákat [28]. Az EVH azonban elengedhetetlen a nikkel-titánium (NiTi) műszerek alkalmazásánál is. Annak ellenére, hogy ezek a müszerek nagyon rugalmasak, $E V H$ hiányában torzulhatnak és el is törhetnek ciklikus fáradás következtében [27, 28].

A bemeneti kavitás végleges formájának kialakításához a kavitás falait ki kell terjeszteni és simára preparálni, hogy koronai dentin ne akadályozza az EVH-t és a csatorna apikális szakaszának megmunkálhatóságát. Ehhez szükséges a pulpakamra tetejének teljes eltávolítása. A folyamat során alávájások keletkezhetnek a pulpakamra falán, ép foganyag felesleges eltávolítása mellett $[7,8]$. Az EVH további akadálya lehet az orifíciumoknál található dentinpolc. Ennek eltávolításához javasolták korábban a Gates-Glidden- és a Peeso-fúrók használatát, viszont az orifíciumok túlzott feltágítása a külső dentinfal és a furkáció felőli dentinfal elvékonyodásához, ezáltal a fog töréssel szemben mutatott ellenállásának csökkenéséhez vezet $[7,8,13,14,23]$. A törési ellenállás növelésének céljából Clark és Khademi 2010-ben közölte a minimál invazív bemeneti kavitás kialakításának koncepcióját moláris fogak vonatkozásában [8].

\section{Minimál invazív bemeneti kavitás}

A minimál invazív bemeneti kavitás alkalmazását támogató szerzők szerint a hagyományosan kialakított bemeneti kavitás koncepciója alapvetően hibás, mert a kényelmes hozzáférhetőségi forma kialakításával elsősorban a kezelőorvos számára biztosítja a gyökérkezelés elvég- 
zéséhez szükséges feltételeket [7, 8]. Ezen feltételek biztosításával azonban gyakran a fog restaurátummal való ellátásának és hosszútávú megtarthatóságának esélye csökken. A hagyományos bemeneti kavitás kialakításánál javasolt $E V H$ forma kialakítása a pericervikális dentin gyengüléséhez vezet. A pericervikális dentin az alveoláris csontszéltől apikálisan és koronálisan számított 4-4 mm foganyagot jelenti [8]. A fognyaknál található dentin vastagsága kulcsfontosságú a fog helyreállíthatósága és a fog szerkezeti integritása szempontjából. A fog nyaki régiója kapja a legtöbb terhelést funkció közben [2], ezért itt fordul elő a legtöbb fraktúra [17], ami gyakran - Touré és mtsai. (2011) szerint az esetek 15,1\%-ban [33]. - szerepel a gyökérkezelt fogak eltávolításának indokaként [12, 35].

A fogak törési ellenállása közvetlen összefüggést mutat a megmaradt ép foganyag mennyiségével $[6,13$, 17, 32]. Kisőrlőket vizsgálva megállapították, hogy a bemeneti kavitás önmagában csak kis hatással $(5 \%)$ van a fog szilárdságára. Azonban, ha ez az approximális zárólécek preparációjával is jár (MOD kavitás), akkor már $63 \%$-os csökkenést figyelhetünk meg [13, 17].

A dentin - összetételének köszönhetően - rugalmas szövet, törékenysége kisebb, mint a zománcé, akár még alámenősen is megfelelő ellenállással rendelkezik. Clark és Khademi (2010) megfigyelése szerint ezek az alámenős területek nagy értéket képviselhetnek a fog számára. A szerzők szerint a pulpaszarvak felett megmaradó 0,5-3 mm széles dentinperem hasonlóan egy abroncshoz, belső merevítésként szolgálhat a fog számára [8] A dentinperem alól a pulpaszarvak ultrahangos eszközökkel és átöblítőszerekkel mikroszkópos kontroll alatt teljes mértékben eltávolíthatók, a terület áttisztítható [23].

Gyökértömött fogaknál a koronai zárás döntő fontosságú, befolyásolja a gyökérkezelés hosszútávú sikerességét. Megfelelő abroncshatás biztosítása a nyaki régióban elengedhetetlen egy jól záró korona készítéséhez. Csapos múcsonk készítéséhez minimum $2 \mathrm{~mm}$ magas és minimum $1 \mathrm{~mm}$ széles ép foganyag szükséges $[8,17]$. Csappal ellátott fog esetében alacsony kockázattal akkor számolhatunk, ha csak az egyik approximális fal hiányzik. Ha hiányzik a bukkális/orális fal vagy csak a bukkális és orális fal található meg, akkor közepes kockázattal kell számolnunk a hosszútávú sikeresség szempontjából [17]. Ezek alapján elmondható, hogy a legjobb megközelítés a gyökérkezelt fogak helyreállíthatósága érdekében az, hogy minimalizáljuk az ép foganyag eltávolítását, különösen a nyaki régióban az abroncshatás megvalósulása érdekében [10, 32].

\section{Minimál invazív bemeneti kavitás kialakítása a gyakorlatban}

Minden jól kialakított bemeneti kavitás egyensúlyt képez a konzervatív és kényelmi forma között és a lehető legkevesebb ép foganyag feláldozásával biztosítja az ideális hozzáférhetőséget a gyökércsatornákhoz [4].
Minimál invazív bemeneti kavitás kialakításához szükséges a fog anatómiájának részletes tanulmányozása. A kavitás tervezéséhez első lépésként a kiindulási röntgenfelvétel / felvételek vagy a még pontosabb háromdimenziós képet adó Cone Beam CT (CBCT)-felvétel gondos elemzésére van szükség. Meg kell figyelni a pericervikális régió anatómiáját, a gyökércsatornák lefutását, a pulpakamra magasságát és alapjának szélességét mesio-distalis, és mélységét vestibulo-oralis irányban. Figyelembe kell venni a szuvasodás, illetve a cserére szoruló restaurátum helyzetét $[4,23]$. Mivel a legnagyobb görbülethez biztosított $E V H$ a pericervikális és furkációs dentin károsodásával járhat, az orifíciumokhoz érdemes egyenes vonalú hozzáférhetőséget tervezni (orifice-oriented access) [11, 23]. Ezzel csatornánként $0,97 \pm 0,32 \mathrm{~mm}$ vastag pericervikális dentin eltávolítása előzhető meg egy mikro CT- analízissel készült vizsgálat szerint [11].

A módszert leíró szerzők nem értenek egyet azzal, hogy minden csatornabemenetnek egyszerre kell láthatónak lennie a tükörben, mivel ez túlzottan sok dentin eltávolítását teszi szükségessé $[1,23]$. A minimál invazív bemeneti kavitás kisebb méretéből adódóan korlátozza a látási viszonyokat. Az emberi szem felbontóképessége kb. 0,2 mm, ami operációs mikroszkóp (OM) használatával 0,6 $\mu \mathrm{m}$-re növelhető. Így kijelenthető, hogy ez a kavitásforma csak nagyítás és megfelelő megvilágítás használata mellett alakítható ki megbízhatóan $[3,5,6,18,20,22,23,27,30,36]$.

A kezelést befolyásolja a fog pozíciója a fogívben, dőlése, a szájnyitási korlátozottság, a kalcifikáció mértéke, valamint a kezelőorvos képzettsége, gyakorlottsága és technikai felkészültsége. A trepanációs kavitás kialakításának első fázisa a pulpakamra tisztítása, amely során szükséges az orifíciumokhoz az EVH-t akadályozó dentin és zománc eltávolítása. Gyémántbevonatú vagy bevonattal nem rendelkező ultrahangos fejek használatával vízhütés nélkül is finoman preparálható a pulpakamra alja és falai, így a látási viszonyok is jobbak [6] (1. kép). A második fázisban a csatornabemenetek megkereséséhez az egészséges foganyag megőrzése érdekében mikro-műszereket (pl. micro-openert vagy pilot-reszelőt) és speciális endodonciai fúrókat is alkalmazhatunk [6]. Ezek a hosszú szárú és nyakú, kis fejü acélgömbfúrók, elsősorban mikroszkópos munkához (2. kép). Minimál invazív bemeneti kavitás esetén a gyökércsatornák megmunkálásához rugalmas ötvözetből készült tágítókat kell választani. NiTi file-ok használatával a gyökércsatornák eredeti lefutása megőrizhető a preparáció során $[6,18,30]$.

\section{A minimál invazív bemeneti kavitások morfológiája}

A minimál invazív bemenetképzés nem feltétlenül jelent extrém kisméretú bemeneti kavitásokat $[8,23]$. Ha a pulpakamra alapja széles és a gyökércsatornák lefu- 
tása megközelítőleg egyenes, lehetőség nyílik két különálló bemenet készítésére a mesialis és distalis gyökércsatorna-rendszerek számára. Ebben az esetben a pulpakamra tetejének középső része érintetlen marad (truss), ezáltal a fog húzó- és nyomóerőkkel szemben ellenállóbb maradhat [8]. Keskeny pulpakamra alappal és konvergáló vagy erősen görbült gyökércsatornákkal rendelkező fogaknál $X$ alakú, más néven lépcsős bemenet alakítható ki. A kavitás ilyenkor leginkább egy homokórára hasonlít: a pulpakamra alapja felé és occlusalis irányba is széttérő. Széles alap és erősen konvergáló csatornák, valamint keskeny alapú, de egyenes lefutású csatornák esetén a bemeneti kavitás gyakran egy csonkagúlához hasonlít (3. kép). Lehetőségünk van egy meglévő approximális restaurátumon vagy szuvas, de már kitisztított lézión keresztül, az occlusalis felszín megnyitása nélkül is elvégezni a gyökérkezelést, ha az egyenes vonalú hozzáférhetőség az orifíciumokhoz így is biztosítható (1. táblázat). A bemeneti kavitás kialakítását kiegészíthetjük a zománcszélek ferdére preparálásával vagy a gyökércsatorna képzeletbeli koronális folytatásának megfelelő kis bevágások készítésével. Így jobb rálátás biztosítható, és a tágító múszerek torzulása is elkerülhető.

1. táblázat

A leggyakoribb minimál invazív bemeneti kavitások kialakításának lehetőségei.

\begin{tabular}{|l|l|l|}
\hline $\begin{array}{l}\text { A pulpakamra } \\
\text { alapja }\end{array}$ & $\begin{array}{l}\text { A gyökércsatorna } \\
\text { lefutása }\end{array}$ & $\begin{array}{l}\text { Bemeneti kavitás } \\
\text { alakja }\end{array}$ \\
\hline \multirow{4}{*}{ széles } & egyenes & $\begin{array}{l}\text { két különálló } \\
\text { bemenet }\end{array}$ \\
\cline { 2 - 3 } & $\begin{array}{l}\text { konvergáló } \\
\text { és/vagy erösen görbült }\end{array}$ & csonkagúla \\
\hline \multirow{3}{*}{ keskeny } & egyenes & csonkagúla \\
\cline { 2 - 3 } & $\begin{array}{l}\text { konvergáló } \\
\text { és/vagy erösen görbültt }\end{array}$ & X vagy lépcsős \\
\hline
\end{tabular}

\section{A minimál invazív bemeneti kavitás értékelése az irodalom alapján}

Megfelelő bemeneti kavitás hiányában nehézségbe ütközik a pulpaür teljes feltárása. Nem maradhat a mikroorganizmusok szaporodásához rejtett zug, mint például egy feltáratlanul maradt pulpaszarv a pulpakamra tetejének részleges eltávolítása esetén [27, 29]. Neelakantan és mtsai. (2018) a pulpakamrában és a mesialis gyökércsatornákban maradt szövettörmelék mennyiségét vizsgálták hagyományos és két különálló / truss bemeneti kavitás esetén. A gyökércsatornákban nem találtak különbséget, a pulpakamrában azonban szignifikánsan több szövettörmelék maradt minimál invazív bemeneti kavitás esetén [24]. A csak részlegesen feltárt pulpakamra ezen túl növeli az esélyét annak, hogy feltáratlan gyökércsatorna marad a kezelt fogakban [21, 29].

A nagyítás használatának előnyét a járulékos csa-

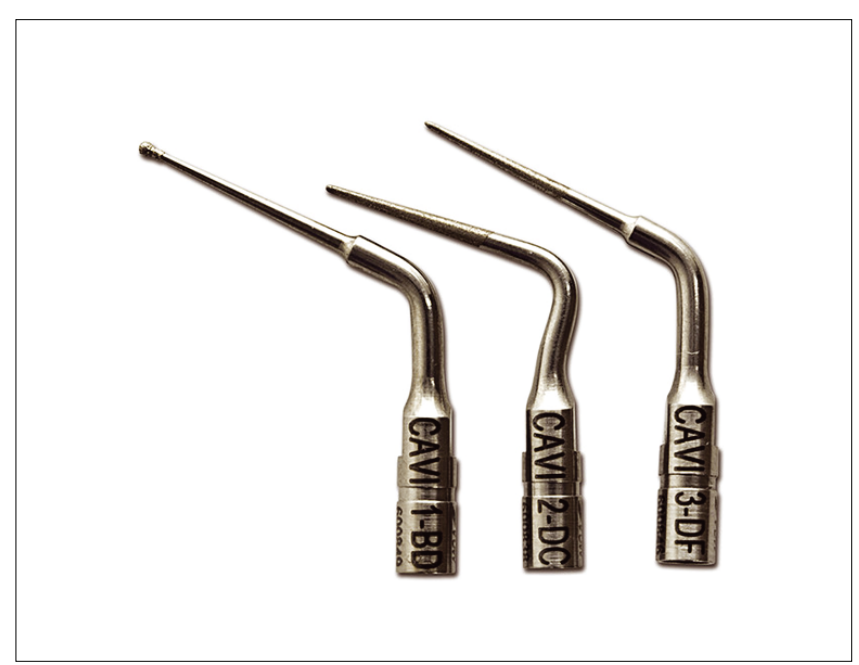

1. kép: Gyémántbevonatú ultrahangos preparáló fejek a pulpakamra falainak minimál invazív alakításához (VDW Diamond-coated CAVI tips) [16].

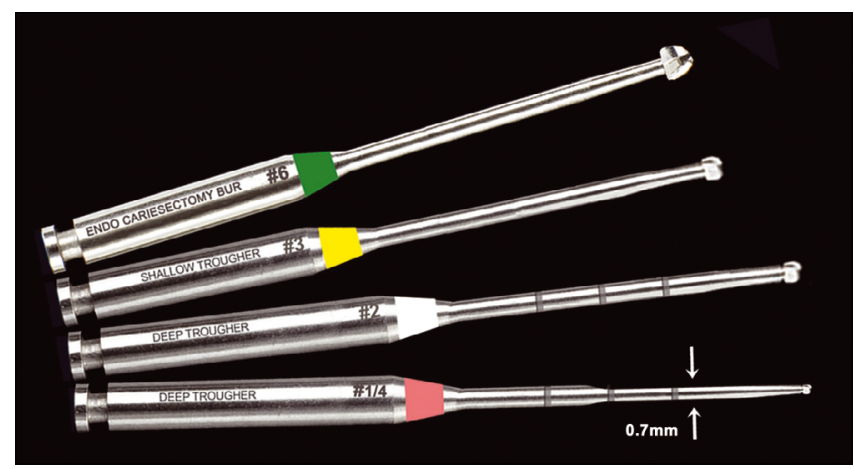

2. kép: Endodonciai fúrók

csatornakereséshez és dentin szelektív eltávolításához (CJM Engineering - Munce Discovery Burs) [15]
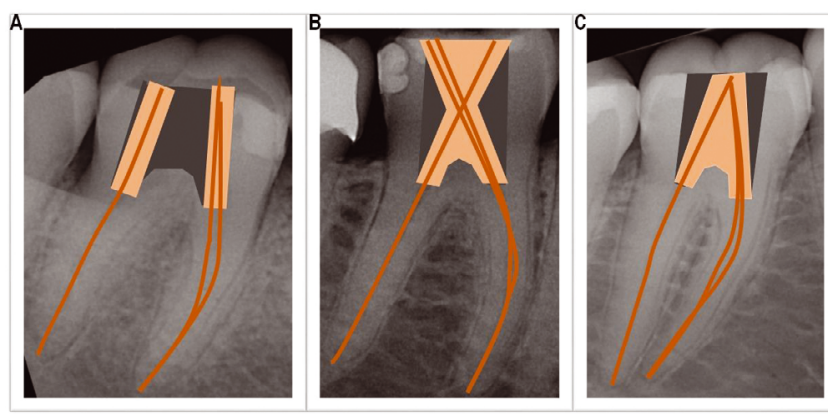

3. kép: Minimál invazív bemeneti kavitások sémás ábrázolása a hagyományossal szemben:

A: két különálló bemenet, $B: X$ vagy lépcsős, $C$ : csonkagúla alakú.

tornák lokalizálhatóságában már több vizsgálatban is bizonyították. Az egyik tanulmány azt mutatja, hogy nagyítás alkalmazásával - akár lupe, akár operációs mikroszkóp (OM) - felső moláris fogakban a mesiobuccalis 2 (MB2) csatorna észlelése háromszor sikeresebb volt, mint nagyítás nélkül, de nem volt szignifikáns kü- 
lönbség a lupéval vagy OM segítségével végzett kezelések között [5]. Egy másik vizsgálatban, ahol fogorvostan-hallgatók végezték a vizsgálatokat, OM segítségével szignifikánsan nagyobb arányban észlelték a gyökércsatorna-bemeneteket, mint lupéval vagy szabad szemmel [36]. Minimál invazív bemeneti kavitások vonatkozásában eddig csak egy in vitro tanulmány készült. Szabad szemmel, OM segítségével, valamint OM és ultrahangos preparáló eszközök segítségével végezték a vizsgálatot felső első moláris fogakon. Minimál invazív bemeneti kavitás esetén szignifikánsan kevesebb MB2 gyökércsatorna feltárása volt lehetséges OM segítségével, de OM és ultrahangos preparálás együttes alkalmazásával már közel azonos eredményt értek el [30]. Ezek alapján kijelenthető, hogy minimál invazív bemeneti kavitás esetében feltétel, hagyományos bemenet esetén pedig rendkívül hasznos az OM használata [30]. Figyelembe kell venni, hogy a felső molárisok mesiobuccalis gyökércsatorna-rendszere kihívást jelenthet a járulékos csatornák lokalizálhatósága és feltárhatósága miatt. A minimál invazív bemeneti kavitás nem minden esetben alkalmas ezeknél a fogaknál [22].

A minimál invazív bemeneti kavitás Clark és Khademi (2010) által megfogalmazott célja a pericervikális dentin védelme és megörzése [8]. Krishan és mtsai. (2014) felső nagymetsző, alsó második premoláris és alsó első moláris fogakon vizsgálta az eltávolított dentin menynyiségét hagyományos és minimál invazív bemenetek esetén. A vizsgálat során kiderült, hogy a módszer minden fogcsoportban kevesebb dentin eltávolításával járt összességében, de szignifikáns különbség csak a koronai részben volt, a gyökércsatorna koronális egyharmadában nem [19]. Egy másik vizsgálatban megfigyelték, hogy minimál invazív bemenet esetén a tágítás akaratlanul a kavitás megnagyobbodásához vezetett gépi forgó müszerek használatával. A kezelőorvosnak figyelembe kell vennie a bemenetképzésnél azt, hogy milyen méretű legyen a kavitás ahhoz, hogy a gépi tágítókban keletkező felesleges stresszt elkerülje [25].

A következő vizsgálatokban a gyökércsatornák megmunkálásának hatékonyságát vizsgálták. Rover és mtsai. (2017) felső első molárisokat vizsgáltak, a tágításhoz Reciproc (VDW München, Németország) rendszert használtak. A preparálatlan gyökércsatorna-felszínek arányában nem volt szignifikáns különbség, ahogyan a felhalmozódott dentintörmelék mennyiségében sem a minimál invazív és a hagyományos bemeneti kavitáson keresztül végzett tágítás után. A vizsgálat során azonban azt észlelték, hogy a distobuccalis és palatinalis csatornák lefutása részben megváltozott, a csatornák áthelyeződtek [30]. A Moore és mtsai. (2016) által felső molárisokon végzett vizsgálatban is hasonló eredményre jutottak. A megmunkálás hatékonysága összességében a minimál invazív és a hagyományos bemeneti kavitás esetében is alacsony volt, viszont nem volt szignifikáns különbség a két csoport között. A minimál invazív bemeneti kavitás nem veszélyeztette a csatorna megmunkál- hatóságát, nem fordult elő műszertörés vagy lépcsőképződés a kísérlet során. A tágítást $V$-Taper2H (SS White Lakewood, USA) rendszerrel végezték [22]. A kutatócsoport korábban alsó első molárisokkal is végzett hasonló vizsgálatokat, ahol a teljes csatornát nézve viszont a distalis csatornában szignifikánsan nagyobb volt a minimál invazív csoportban a preparálatlan felszínek aránya. A különbséget az apikális gyökéri harmadban találták a legnagyobbnak [19].

A minimál invazív kezelés - több foganyag megőrzéséből következően - a törési ellenállás növekedését ígéri. Ezzel kapcsolatban több ex vivo vizsgálat is zajlott, egymásnak helyenként ellentmondó eredménnyel. Restaurátummal ellátott felső molárisoknál például nem volt szignifikáns különbség a töréssel szemben mutatott ellenállásban a hagyományos és a minimál invazív csoport között [22, 30]. Özyürek és mtsai. (2018) minimál invazív (truss) és hagyományos bemenetet alakítottak ki mesio-occlusalis kavitásokból alsó molárisokban. A gyökércsatornák tágítása és tömése után a fogat kompozit restaurátummal látták el. Ebben a vizsgálatban sem volt szignifikáns különbség, a fraktúra minőségét vizsgálva azonban a minimál invazív csoportban szignifikánsan több restaurálható fogat találtak [26]. Más kísérletben, ahol a fogakat nem látták el semmilyen restaurátummal és üreget csak occlusalisan alakítottak ki, a premolárisok és molárisok kontroll- és minimál invazív csoportja szignifikánsan ellenállóbbnak mutatkozott, mint a hagyományos csoport. A vizsgálat során megfigyelték, hogy premolárisoknál a fractura a minimál invazív csoportban csak a csücsköket érintette, nem pedig a kavitás teljes falát [19]. Plotino és mtsai. (2017) kísérletüket az ultrakonzervatív „ninja” bemeneti kavitással kibővítve végezték. Direkt restaurátummal ellátott alsó és felső premolárisokat és molárisokat vizsgáltak statikus terhelésnek kitéve a fogakat. A hagyományos csoport szignifikánsan alacsonyabb törési ellenállást mutatott, mint a kontroll, minimál invazív és „ninja” csoportok. A „ninja” bemenet nem növelte a törési ellenállást a minimál invazívhoz képest. Itt is vizsgálták a fraktúra minőségét. Az összes preparált csoportban a nem helyreállítható törések száma volt szignifikánsan magasabb a nem preparált kontrollcsoporthoz képest, az egyes csoportok között azonban nem volt szignifikáns eltérés [29]. A bemeneti kavitás restaurátummal való ellátásának módja a fogak töréssel szemben mutatott ellenállását nagyban befolyásolja. Ezért továbbra is a csücsköket vagy a teljes fogat borító definitív restaurátum készítése javasolt posterior fogak esetében [22]. Az eddigi vizsgálatokat összesítő szisztematikus áttekintés alapján egyelőre nincs tudományos bizonyíték, amely alátámasztaná, hogy a minimál invazív bemeneti kavitás a hagyományossal szemben szignifikánsan növelné a gyökérkezelt fogak törési ellenállását [31].

Niemi és mtsai. (2016) megemlítették, hogy a vizsgálatukban felhasznált alsó kisőrlő fogak esetében a minimál invazív bemeneti kavitás nem tette lehetővé a continous wave technikával való gyökértömés elké- 
szítését. Moláris fogaknál nagyobb az esély arra, hogy ezzel a technikával elegendő hely áll rendelkezésre a gyökértömés kivitelezéséhez [25].

Bóveda és Kishen (2015) javasolják a CBCT rutinszerü használatát minimál invazív bemenetképzés tervezésénél [3]. Connert és mtsai. (2014) szerint azonban nincs szignifikáns különbség az eltávolított dentin mennyiségében a CBCT és a periapikális röntgenfelvétel alapján tervezett bemeneti kavitások esetében, így a CBCT-felvétel ilyen szempontból nem jelentett előnyt a tervezésnél [9]. Az azonban kétségtelen, hogy a CBCT nyújtotta nagy felbontású, részletgazdag felvételen jól értékelhetők a fog egyedi anatómiai jellemzői. Zehnder és mtsai. (2016) pre- és postoperatív CBCT segítségével értékelték az in vitro 3 dimenzióban digitálisan tervezett, irányított gyökérkezeléseket („guided endodontics"), és azt találták, hogy a nyomtatott sablon használatával pontos bemeneti kavitást és a gyökércsatornák apikális harmadig való jó hozzáférhetőségét lehet biztosítani [37].

Az eddigi vizsgálatokon túl további ex vivo vizsgálatokra van szükség, hogy a gyökércsatorna-tágítás, -tisztítás és -fertőtlenítés minőségét meg tudjuk ítélni. Ezt követően randomizált esetkontrollos vizsgálatok, valamint retrospektív és prospektív vizsgálatok is szükségesek, melyek eredményeinek függvényében a megfelelő indikációkban megfontolható a minimál invazív bemeneti kavitás kialakításának rutinszerü alkalmazása [31].

\section{Összefoglalás}

Minimál invazív bemenetképzés esetén a pulpakamrában több szövettörmelék marad, ezért ennek eltávolításához operációs mikroszkóp és ultrahangos preparáló fejek használata javasolt. Ezen eszközök alkalmazása továbbá javítja az összes gyökércsatorna megtalálásának esélyét, ahogyan kiindulási CBCT-felvétel készítése is, amely a bemeneti kavitás tervezésében is segítségünkre lehet. A minimál invazív módszer pericervikális dentinre gyakorolt védő hatását nem sikerült még kimutatni, viszont a fog koronai részében egyértelmúen több foganyag marad, ami a fog restaurálhatóságát nézve nem utolsó szempont. A tágító múszerek erős deformációja ellenére a megmunkálás hatékonyságában és sikerességében nincs különbség, bár a gyökércsatornák áthelyeződésével számolni kell. Egyelőre nincs bizonyíték arra vonatkozóan, hogy a minimál invazív módszerrel növelhető lenne a fog törési ellenállása.

Összefoglalásképpen elmondható, hogy a gyökérkezelés megbízhatóan kivitelezhető megfelelő tárgyi és személyi feltételek esetén minimál invazív bemeneti kavitáson keresztül is, de egyelőre még nem sikerült in vitro vizsgálatok alapján teljes mértékben igazolni a módszer előnyeit, illetve egyetlen klinikai vizsgálat sem készült a kezelés sikerességének vonatkozásában.

\section{Irodalom}

1. Adams N, Tomson PL: Access cavity preparation. Br Dent J. 2014: 333-339.

2. AsUNDI A, KISHEN A: A strain gauge and photoelastic analysis of in vivo strain and in vitro stress distribution in human dental supporting structures. Arch Oral Biol. 2000: 543-550.

3. BóvedA C, KISHEN A: Contracted endodontic cavities: the foundation for less invasive alternatives in the management of apical periodontitis. Endodontic Topics. 2015: 169-186.

4. BuCHANAN LS: Cutting endodontic access cavities - for long-term outcomes. Roots. 2015: 60-63.

5. Buhrley LJ, Barrows MJ, BeGole EA, Wenckus CS: Effect of magnification on locating the MB2 canal in maxillary molars. J Endod. 2002: 324-327.

6. BürkLEIN S, SChAfER E: Minimally invasive endodontics. Quintessence Int. 2015: 119-124.

7. Clark D, Khademi JA: Case Studies in Modern Molar Endodontic Access and Directed Dentin Conservation. Dent Clin N Am. 2010: 275-289.

8. Clark D, Khademi JA: Modern Molar Endodontic Access and Directed Dentin Conservation. Dent Clin N Am. 2010: 249-273.

9. Connert T, Rein D, ElAyouti A, Godt A: Does CBCT help to reduce the amount of dentine removal during access cavity preparation? - abstract. Int Endod J. 2014: 50-113.

10. Dietschi D, Duc O, Krejci I, Sadan A: Biomechanical considerations for the restoration of endodontically treated teeth: a systematic review of the literature, Part II (Evaluation of fatigue behavior, interfaces, and in vivo studies). Quintessence Int. 2008: 117-129.

11. Eaton JA, Clement DJ, Lloyd A, Marchesan MA: Micro-Computed Tomographic Evaluation of the Influence of Root Canal System Landmarks on Access Outline Forms and Canal Curvatures in Mandibular Molars. J Endod. 2015: 1888-1891.

12. FAZEKAS Á: A pulpaür anatómiája, bemeneti cavitas preparálása és a gyökércsatorna hosszának meghatározása. In FAZEKAS Á (szerk.): Megtartó fogászat és endodoncia. Semmelweis Kiadó, Budapest, 2006; 287-297.

13. Gluskin AH, Peters C, Peters OA: Minimally invasive endodontics: challanging and prevailing paradigms. Br Dent J. 2014: 347353.

14. Gutmann JL: Minimally invasive dentistry (Endodontics). J Cons Dent. 2013: 282-283.

15. http://www.dentalproductshopper.com/munce-discovery-burs

16. https://www.vdw-dental.com/en/products/detail/cavi-tips/

17. Jotкowitz A, SAmet N: Rethinking ferrule - a new approach to an old dilemma. Br Dent J 2010: 25-33.

18. Khademi Ja, Trudeau M, Narayana P, Rabi RM, Baerg SD: Imageguided endodontics: the role of the endodontic triad https://www. dentalcetoday.com/courses/261\%2FPDF\%2FDT_August_16_ NPR_Khademi.pdf (2016.10.24.)

19. Krishan R, Paqué F, Ossareh A, Kishen A, Dao T, Friedman S: Impacts of conservative endodontic cavity on root canal instrumentation efficacy and resistance to fracture assessed in incisors, premolars, and molars. J Endod. 2014: 1160-1166.

20. Mamoun JS: The maxillary molar endodontic access opening: A microscope-based approach. Eur J Dent. 2016: 439-446.

21. Mathew ST, Rajan JS: Minimally invasive endodontics. J Dent Oral Hyg. 2014: 36-38.

22. Moore B, Verdelis K, Kishen A, Dao T, Friedman S: Impacts of Contracted Endodonic Cavities on Instrumentation Efficacy and Biomechanical Responses in Maxillary Molars. J Endod. 2016: 1779-1783.

23. Narayana P: Access Cavity Preparations. In Schwartz RS, Canakapalli V (ed.): Best Practices in Endodontics: A Desk Reference. Quintessence Publishing, USA, 2015; 89-103.

24. Neelakantan P, Khan K, Hei Ng GP, Yip CY, Zhang C, Pan Cheung GS: Does the orifice-directed dentin conservation access design debride pulp chamber and mesial root canal systems of man- 
dibular molars similar to a traditional access design? J Endod. 2018: 274-279.

25. Niemi TK, Marchesan MA, Lloyd A, Seltzer RJ: Effect of Instrument Design and Access Outlines on the Removal of Root Canal Obturation Materials in Oval-shaped Canals. J Endod. 2016: 15150-1554.

26. Özyürek T, Ülker Ö, Demiryürek EÖ, Yilmaz F: The effects of endodontic access cavity preparation design on the fracture strength of endodontically treated teeth: traditional versus conservative preparation. J Endod. 2018: 800-805.

27. Patel S, Rhodes J: A practical guide to endodontic access cavity preparation in molar teeth. Br Dent J. 2007: 133-140.

28. Peters OA: Current challenges and concepts in the preparation of root canal systems: a review. J Endod. 2004: 559-567.

29. Plotino G, Grande NM, Isufi A, loppolo P, Pedulla E, Bedini R et al.: Fracture strength of endodontically treated teeth with different access cavity designs. J Endod. 2017: 995-1000.

30. Rover G, Belladonna FG, Bortoluzzi EA, De-Deus G, Silva EJNL, TEIXEIRA CS: Influence of access cavity design on root canal detection, instrumentation efficacy, and fracture resistance assessed in maxillary molars. J Endod. 2017: 1657-1662.
31. Silva EJNL, Rover G, Belladonna FG, De-Deus G, da Silveira TeIXEIRA C, DA SiLva Fidalgo TK: Impact of contracted endodontic cavities on fracture resistance of endodontically treated teeth: a systematic review of in vitro studies. Clin Oral Invest. 2018: 109-118.

32. TANG $W$, Wu $\mathrm{Y}$, Smales RJ: Identifying and reducing risks for potential fractures in endodontically treated teeth. J Endod. 2010: 609-617.

33. Touré B, Faye B, Kane AW, Lo CM, Niang B, Boucher Y: Analysis of reasons for extraction of endodontically treated teeth: a prospective study. J Endod. 2011: 1512-1515.

34. Vertucci FJ, HadDIX JE: Tooth Morphology and Access Cavity Preparation. In Hargreaves KM, Cohen S: Cohen's Pathways of the Pulp. (10th ed.) Elsevier, St. Loius, 2010; 136-222.

35. VIRE DE: Failure of endodontically treated teeth: classification and evaluation. J Endod. 1991: 338-342.

36. Yoshioka T, KobaYASHI C, SUdA H: Detection rate of root canal orifices with a microscope. J Endod. 2002: 452-453.

37. Zehnder MS, Connert T, Weiger R, Krastl G, Kühl S: Guided endodontics: accuracy of a novel method for guided access cavity preparation and root canal location. Int Endod J. 2016: 966-972.

BalÁzs M, Komora P, Tóth Zs

\section{Minimally invasive access cavity in premolars and molars - review}

There is an increasing number of case presentations in the social media and scientific forums, in which dentists and endodontists perform successful root canal treatments through tiny access cavities. This technical achievement cannot be carried out without proper instruments, magnification (operating microscope) and lighting. With a minimally invasive access cavity the root canal treatment itself can be complicated and time-consuming. In case of a tooth with complex anatomy the use of this method is limited. On the other hand, in simpler cases, if debris is eliminated and the pulp cavity is disinfected properly, it can be a real alternative for traditional access cavities. It enables us to preserve more coronal tooth structure, which makes final restoration easier to do, but the increase in fracture resistance has not been proved yet in vitro.

Keywords: minimally invasive access cavity, pericervical dentin, orifice oriented access, fracture resistance, operating microscope

\section{Pályázat Körmöczi-pályadíjra}

Felhívjuk minden, a Fogorvosi Szemlében publikáló, rendezett MFE tagsággal rendelkező, 35 évnél fiatalabb első szerzős cikk szerzőjét, hogy pályázzanak a 2018-as Körmöczi-pályadíjra.

Pályázni csak a 2018-ban a Fogorvosi Szemlében megjelent közleményekkel lehet. Kérjük, a közlemény pdf változatát mellékelje a pályázathoz.

\section{A pályázat beadási határideje: 2019. február 4.}

A pályázatokat, kérem, emailen juttassák el címemre!

$$
\begin{aligned}
& \text { Dr. Fejérdy Pál } \\
& \text { az MFE főttitkára }
\end{aligned}
$$

fejerdy.pal@dent.semmelweis-univ.hu 